\title{
6. STRONTIUM-ISOTOPIC DATING OF NERITIC CARBONATES AT BOUGAINVILLE GUYOT (SITE 831), NEW HEBRIDES ISLAND ARC ${ }^{\prime}$
}

\author{
Terrence M. Quinn, ${ }^{2}$ F.W. Taylor,${ }^{3}$ and A.N. Halliday ${ }^{4}$
}

\begin{abstract}
Drilling at Bougainville Guyot (Ocean Drilling Program Site 831), New Hebrides Island Arc during Leg 134 revealed that $727.5 \mathrm{~m}$ of carbonate overlies an andesite basement. The carbonate cap at Site 831 consists of $20 \mathrm{~m}$ of pelagic carbonate overlying $707.5 \mathrm{~m}$ of neritic carbonates. The neritic section consists of $\sim 230 \mathrm{~m}$ of largely unaltered aragonite sediment that overlies $\sim 497$ $\mathrm{m}$ of totally calcitized limestone. The deeper portion of the calcitized interval has been pervasively altered by diagenesis. Prior to this study the age distribution of sediments at Bougainville Guyot was poorly known because age diagnostic fossils are sparsely and discontinuously distributed in the sequence.

We have used $\mathrm{Sr}$ isotopes to provide temporal constraints on the deposition of carbonates at Site 831; these constraints are critical in reconstructing the vertical movement of Bougainville Guyot before its collision with the New Hebrides Island Arc. Overall, the chronostratigraphy of Bougainville Guyot can be subdivided into three intervals: (1) a Pleistocene interval (102.4 to 391.11 meters below sea floor [mbsf]); (2) a Miocene interval ( 410.31 to $669.53 \mathrm{mbsf}$ ); and (3) an Oligocene interval (678.83 to $727.50 \mathrm{mbsf}$ ). Strontium isotopic ages of samples increase with increasing depth in the carbonate sequence, except near the bottom of the sequence, where several samples exhibit a consistent reversed age vs. depth trend. Such age reversals are most likely the product of post-depositional rock-water interaction. Preliminary stable isotope data are consistent with diagenetic alteration in the marine and meteoric environments. Several abrupt decreases in $8^{87} \mathrm{Sr}$, and hence age, of sediments are recognized in the carbonate cap at Bougainville Guyot. These disconformities are most likely the product of subaerial exposure in response to relative sea-level fall. Indeed, $\mathrm{Sr}$-isotope ages indicate that 2 to $9 \mathrm{~m}$.y. of sediment deposition is missing across these $\delta^{87} \mathrm{Sr}$ disconformities.
\end{abstract}

\section{INTRODUCTION}

Strontium isotopes have successfully been used to date sediment deposition and diagenesis in Cenozoic neritic carbonate sequences (e.g., Swart et al., 1987; Vahrenkamp et al., 1988; Ludwig et al., 1988; Saller and Koepnick, 1990; Quinn et al., 1991). The basic premise of using $\mathrm{Sr}$ isotopes as a stratigraphic and chronostratigraphic tool requires that the seawater ${ }^{87} \mathrm{Sr} /{ }^{86} \mathrm{Sr}$ ratio at the time of sediment deposition be preserved in, or can be deciphered from, the measured ${ }^{87} \mathrm{Sr} /{ }^{86} \mathrm{Sr}$ ratio of the sample. The potential for diagenetic alteration of primary ${ }^{87} \mathrm{Sr} /{ }^{86} \mathrm{Sr}$ ratio of neritic carbonates is considerable because such sediments are deposited as metastable carbonate minerals (Mg-calcite and aragonite), and they are affected by a variety of pore fluids during their diagenetic history. Previous Sr-isotope studies of neritic carbonates from atolls and guyots indicate that early freshwater diagenesis commonly results in the preservation of depositional $\mathrm{Sr}$-isotope ratios (e.g., Ludwig et al., 1988; Saller and Koepnick, 1990; Quinn et al., 1991). However, stratigraphic redistribution of $\mathrm{Sr}$ has also been recognized in such environments (Quinn et al., 1991). The latter individuals used stable isotope evidence, specifically low $\delta^{13} \mathrm{C}$ values, together with water-dominated $\delta^{18} \mathrm{O}$ values, to identify samples having "anomalous" $\mathrm{Sr}$-isotope values. We employ a similar strategy in this study.

The Oligocene to Holocene carbonate sequence at Bougainville Guyot is well suited for Sr-isotopic dating for two reasons. First, previous application of $\mathrm{Sr}$-isotopic dating to carbonates from Anewetak Atoll, which are similar to those recovered at Site 831, has demonstrated the validity of this approach and has provided important constraints on the geologic history of this atoll (e.g., Ludwig et al., 1988; Saller and Koepnick, 1990; Quinn et al., 1991). Second, vari-

${ }^{\prime}$ Greene, H.G., Collot, J.-Y., Stokking, L.B., et al., 1994. Proc. ODP, Sci. Results, 134: College Station. TX (Ocean Drilling Program).

${ }^{2}$ Department of Geology, University of South Florida, Tampa, FL 33620-5200, U.S.A.

${ }^{3}$ Institute for Geophysics, University of Texas-Austin, Austin, TX 78759, U.S.A.

${ }^{4}$ Department of Geological Sciences, University of Michigan, Ann Arbor, MI 48109. 1063, U.S.A. ation in seawater Sr-isotopic composition from the Oligocene to Holocene is such that temporal resolution over much of this interval is better than 1.0 m.y. (e.g., DePaolo, 1986; Hess et al., 1986; Hodell et al., 1989, 1990, 1991). Generation of a Sr-isotope stratigraphy (SIS; Ludwig et al., 1988) will significantly increase the temporal resolution of neritic carbonate sediments at Bougainville Guyot.

Site 831 is located at $16^{\circ} 00.51^{\prime} \mathrm{S}, 166^{\circ} 40.36^{\prime} \mathrm{E}$, in a water depth of $1077.6 \mathrm{mbsf}$. Site 831 is located roughly in the center of the flat-topped platform of Bougainville Guyot, approximately $42 \mathrm{~km}$ southwest of the southern tip of Espiritu Santo Island (Fig. 1). Two holes were drilled at Site 831: Hole 831A, which was drilled to a total depth of 116.5 mbsf, and Hole 831B, which was washed down to a depth of 102.4 mbsf and cored for $749.6 \mathrm{~m}$. Core recovery was poor in both holes, averaging $22.4 \%$ in Hole $831 \mathrm{~A}$ and $11.6 \%$ in Hole $831 \mathrm{~B}$. The focus of this study is the neritic carbonate interval (102.4 to $727.5 \mathrm{mbs}$ ) in Hole 831B. Unfortunately, core recovery in the neritic carbonate interval averaged $<5 \%$. Thus, we are left with the challenge of putting together a coherent story from a largely discontinuous recovered record.

The reconstruction of the geodynamic and paleoceanographic history of Bougainville Guyot was one of the primary objectives of drilling at Site 831 . This objective can best be achieved by the dating and chemical analyses of guyot and basement rocks recovered during drilling. Radiometric analyses (K/Ar) of andesite basement samples indicate that basement rocks are as young as $37 \pm 0.1 \mathrm{Ma}$ (see Rex, this volume; Baker et al., this volume). Chronology of guyot carbonates, based on large foraminiferal biostratigraphy, is poorly known and insufficient to meet the scientific objectives because age-diagnostic fossils are sparsely and discontinuously distributed in the carbonate cap (Fig. 2). For example, the shallowest $220 \mathrm{~m}$ of carbonate is assigned a Pliocene or Pleistocene age. No age-diagnostic fossils were recognized in the interval from 246 to 564 mbsf. An early Miocene and late Oligocene age was estimated for the interval from 564 to 727 mbsf. Thus, despite the great thickness of carbonate at Bougainville Guyot, the age of this sequence remains poorly known.

The objective of this study is to use $\mathrm{Sr}$ isotopes to date the neritic carbonate cap of Bougainville Guyot. To meet this objective, we 


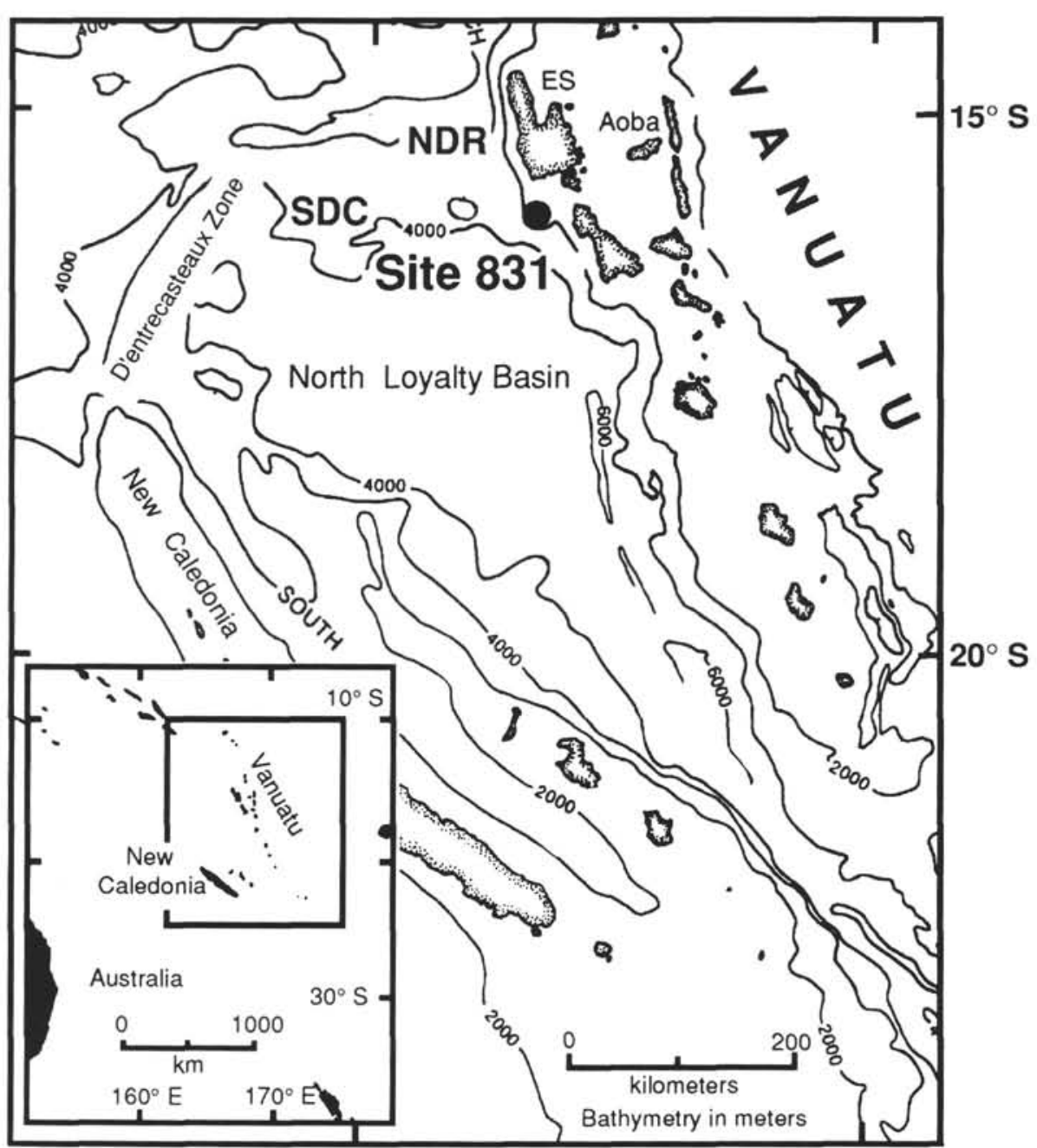

Figure 1. Location map. Holes $831 \mathrm{~A}$ and $831 \mathrm{~B}$ were drilled at Site 831 during Leg 134 in roughly $1077 \mathrm{~m}$ water depth. NDR = North d'Entrecasteaux Ridge, SDC $=$ South d'Entrecasteaux Chain of guyots, ES = Espiritu Santo Island.

generated a Sr-isotope stratigraphy (Ludwig et al., 1988) from neritic carbonate samples recovered at Hole 831B during Leg 134.

\section{BACKGROUND}

Previous work on the carbonate cap at Bougainville Guyot focused on sedimentologic and biostratigraphic analyses of neritic carbonates recovered during (1) submersible diving and dredging operations (Montaggioni et al., in press; Collot et al., 1992) and (2) shipboard analyses completed during Leg 134. Results of the latter analyses are summarized in Figure 2, whereas results of the former are discussed in more detail below.

The oldest rock recovered during submersible diving and dredging operations was a coarse volcanic breccia with basaltic clasts and chalk matrix, dated as uppermost middle Eocene ( 40 to $42 \mathrm{Ma}$ ) by nannofossil biostratigraphy (Collot et al., 1992). Large foraminiferal biostratigraphy suggests that reefal carbonates were deposited during the late Oligocene to early Miocene, and latest Miocene to early Pliocene (Collot et al., 1992). Sedimentologic observations indicate that carbonate samples range from being well preserved (i.e., retention of primary metastable mineralogy) to being diagenetically altered (i.e., dissolution of metastable grains, neomorphism of metastable grains, and intragranular cementation). Biostratigraphy and sedimentology data have been used to reconstruct the development of the carbonate cap at Bougainville Guyot (Montaggioni et al., in press; Collot et al., 1992). According to these authors the initiation of neritic carbonate deposition occurred in the early Oligocene, and that deposition continued intermittently until Pliocene to Pleistocene time. In addition, these authors recognized three hiatuses within the carbonate cap; early Oligocene ( 36 to $32 \mathrm{Ma}$ ), middle Miocene ( 16 to $6 \mathrm{Ma})$, and Pliocene to Pleistocene $(-2.2$ to $0.5 \mathrm{Ma})$.

\section{METHODS}

Powdered samples $(0.5$ to $2.0 \mathrm{mg}$ ) of skeletal allochems, rock matrix, and calcite cement were extracted from hand-samples using a microscope-mounted drill assembly. Mineralogy, minor element, oxygen, carbon, and strontium-isotope composition was determined on these powdered samples. Carbonate mineralogy was determined by standard X-ray techniques and peak-height ratios. Strontium and magnesium contents were measured using a Perkin Elmer Model 403 atomic absorption spectrophotometer using standard wet chemistry techniques (e.g., Quinn, 1991). Results are reported relative to weight of carbonate rock. Precision $( \pm 2 \sigma)$, based on duplicate geochemical 


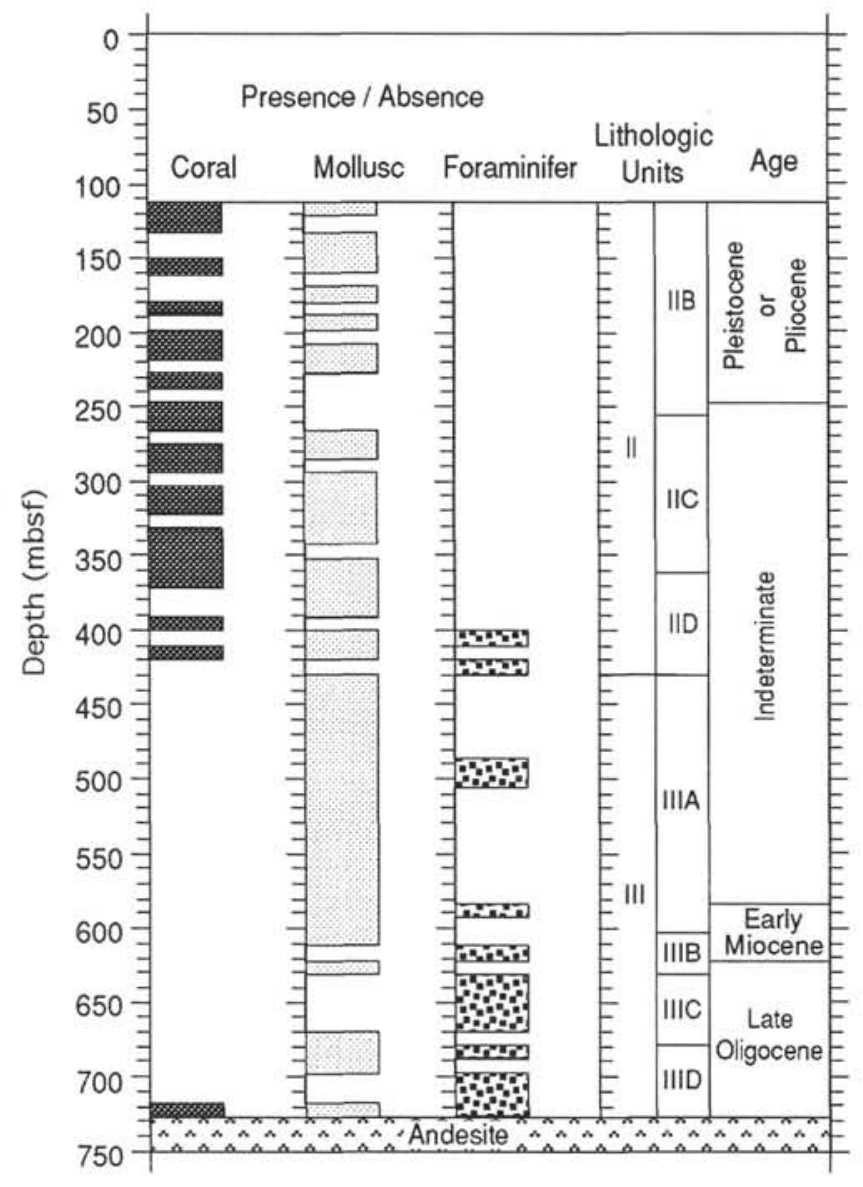

Figure 2. Summary diagram of shipboard lithostratigraphy and biostratigraphy of Hole 831B. Note that despite the great thickness of carbonate at Bougainville Guyot, its chronology is poorly known.

analyses is better than 5\%. Prior to stable isotopic analysis, powdered samples that contained aragonite were vacuum roasted for $1 \mathrm{hr}$ at $200^{\circ} \mathrm{C}$, whereas calcite samples were roasted for $1 \mathrm{hr}$ at $380^{\circ} \mathrm{C}$ to remove volatile contaminants. Samples were reacted with anhydrous phosphoric acid at $75^{\circ} \mathrm{C}$ in individual reaction vessels of a CarboKiel carbonate extraction system coupled to the inlet of a MAT 251 mass spectrometer. Precision $( \pm 1 \sigma)$ was monitored by daily analyses of a powdered calcite standard (NBS-20), and was better than $0.1 \%$ for carbon and oxygen, respectively. Values are reported in standard $\delta$ notation relative to the Chicago PDB standard.

Strontium was separated utilizing standard cation exchange column chemistry and loaded on rhenium single filaments with tantalum oxide and phosphoric acid and analyzed with a VG Sector multicollector mass spectrometer using multidynamic analysis. Over the course of our analyses, 50 analyses of NBS-987 gave a mean of $0.710247 \pm 0.0000018$ ( $2 \sigma$ mean) and 13 analyses of USGS standard EN-1, a proxy for modern seawater, gave a mean of $0.709180 \pm$ 0.0000031 ( $2 \sigma$ mean). We report strontium-isotope data both as ${ }^{87} \mathrm{Sr} /{ }^{86} \mathrm{Sr}$ ratio and $\delta^{87} \mathrm{Sr}$, where $\delta^{87} \mathrm{Sr}=\left(\left[{ }^{87} \mathrm{Sr} /{ }^{86} \mathrm{Sr}_{\text {sample }}{ }^{87} \mathrm{Sr}^{86} \mathrm{Sr}_{\text {moder }}\right.\right.$ seawater $l-1) \times 10^{5}$, following the convention used by Hess et al. (1986) and Hodell et al. (1989).

Strontium-isotopic variation with depth was converted to variation with time via calibration with a record of seawater $\delta^{87} \mathrm{Sr}$ derived from pelagic sediment, whose ages are inferred from bio- and magnetochronology. We used the most recent compilation of Hodell et al. $(1989,1990,1991)$ as a Cenozoic standard and used the program ISOPLOT (Ludwig, 1990) to convert measured Sr-isotopic ratios to age. In short, ISOPLOT first fits a cubic-spline curve both to the seawater $\delta^{87} \mathrm{Sr}$ curve and to the upper and lower error limits of this curve, and then calculates the intersection(s) of a given input $\delta^{87} \mathrm{Sr}$ value and its associated errors with these cubic-spline curves.

\section{RESULTS}

The neritic carbonate interval at Hole $831 \mathrm{~B}$ extends downward $625.1 \mathrm{~m}$, from 102.4 to $727.5 \mathrm{mbsf}$, the depth of the carbonate-basalt contact. Two coral samples recovered from the washdown interval at Hole $831 \mathrm{~B}$ ( 0.0 to $102.4 \mathrm{mbsf}$ ) have been assigned depths of 102.58 and 102.75 mbsf (Table 1). It must be noted, however, that the exact stratigraphic position of these two coral samples is not known, and that they could have been derived from any depth between the sediment-water interface $(0 \mathrm{mbsf})$ and the total washdown depth (102.4 mbsf).

Geochemistry data were generated from samples obtained from this neritic carbonate interval. In Table 1 we report strontium-isotope data, together with $\mathrm{Sr}$ and $\mathrm{Mg}$ contents, on samples from Hole 831B. Also tabulated are the proportions of aragonite to total carbonate. In Table 2 we report $\delta^{18} \mathrm{O}$ and $\delta^{13} \mathrm{C}$ values for several sparry calcite cement samples.

\section{Mineralogy}

The carbonate cap is readily divisible into two mineralogic intervals (Fig. 3). One interval is an upper, relatively unaltered, aragonite-rich interval that extends from 102.4 mbsf to at least 323.52 mbsf (Core 134-831 B-27R), and possibly as deep as $352.35 \mathrm{mbsf}$ (Core 134-831B$30 \mathrm{R})$. The lack of core recovery in Cores $28 \mathrm{R}$ and $29 \mathrm{R}$ makes placing the exact boundary between these two mineralogical intervals ambiguous. The second interval is a lower, pervasively altered, calcite-rich interval that extends from 352.35 to 727.5 mbsf. One sample (134831B-41R-CC, 1-4 cm), within this lower pervasively calcitized interval, contains roughly $25 \%$ dolomite by weight (Fig. 3 ).

\section{Minor Elements}

Strontium and $\mathrm{Mg}$ content was determined for 27 samples (Table 1). Samples from the calcitized portion of the carbonate cap ( 352.35 to $727.5 \mathrm{mbsf}$ ) contain low $\mathrm{Sr}$ content $(<200 \mathrm{ppm})$ and somewhat elevated Mg content (2000 ppm). In stratigraphic context Mg content is somewhat variable between 352.35 and 496.41 mbsf, nearly invariant from 515.82 to $698.64 \mathrm{mbsf}$, and relatively elevated from 707.56 to 727.38 mbsf (Fig. 4). There is no discernible pattern of changes in Sr content with depth (Fig. 4).

\section{Stable Isotopes}

Oxygen and carbon isotope ratios were determined for 11 sparry calcite samples extracted from the pervasively calcitized interval (Table 2). The isotopic composition of these samples cluster into two groupings (Fig. 5). The first grouping contains 8 samples and has average $\delta^{18} \mathrm{O}(\%$ PDB $)$ and $\delta^{13} \mathrm{C}(\%$ PDB $)$ values of $-1.43 \pm 0.51(2 \sigma)$ and $2.23 \pm 0.46(2 \sigma)$, respectively. The second grouping contains 3 samples and has average $\delta^{18} \mathrm{O}(\% \mathrm{PDB})$ and $\delta^{13} \mathrm{C}(\% \mathrm{PDB})$ values of $-5.48 \pm 0.04(2 \sigma)$ and $-3.02 \pm 0.59(2 \sigma)$, respectively.

\section{Strontium Isotopes}

\section{Chemostratigraphy}

$\delta^{87} \mathrm{Sr}$ values vs. depth in mbsf are plotted in Figure 6A. Two coral samples recovered from the washed down interval ( 0 to $102.4 \mathrm{mbsf})$ have $\delta^{87} \mathrm{Sr}$ values that are slightly lower $(-0.268 \pm 0.240$ and -0.620 \pm 0.226 ) than modern values for Holocene calcareous organisms (i.e., 0.0 ). Eight samples, recovered between 140.6 and $265.5 \mathrm{mbsf}$ (Cores $134-831 \mathrm{~B}-7 \mathrm{R}$ to $-21 \mathrm{R})$, have invariant $\delta^{87} \mathrm{Sr}$ values that average 
Table 1. Chemistry of neritic carbonates at Bougainville Guyot (Leg 134, Site 831, Hole 831B).

\begin{tabular}{|c|c|c|c|c|c|c|c|c|c|c|c|c|}
\hline $\begin{array}{l}\text { Core, section, } \\
\text { interval }(\mathrm{cm}) \\
\end{array}$ & $\begin{array}{c}\text { Sample } \\
\text { type }\end{array}$ & $\begin{array}{l}\text { Depth } \\
(\mathrm{mbsf})\end{array}$ & $\begin{array}{l}\text { Calcite } \\
\text { (wt \%) }\end{array}$ & $\begin{array}{c}\mathrm{Mg} \\
(\mathrm{ppm})\end{array}$ & $\begin{array}{c}\mathrm{Sr} \\
(\mathrm{ppm})\end{array}$ & ${ }^{87} \mathrm{Sr} /{ }^{86} \mathrm{Sr}$ & $\pm 2 \sigma$ & $\delta^{87} \mathrm{Sr}^{\mathrm{b}}$ & $\pm 2 \sigma^{c}$ & App. & $\begin{array}{l}\text { Age }^{\mathrm{d}} \\
\text { Min. }\end{array}$ & Max. \\
\hline $1 W-1,18-20$ & $\mathrm{Crl}$ & 102.58 & 9 & & & 0.709134 & 0.000016 & -0.620 & 0.226 & 0.58 & 0.10 & 1.46 \\
\hline $1 \mathrm{~W}-1,35-37$ & $\mathrm{Crl}$ & 102.75 & 9 & & & 0.709159 & 0.000017 & -0.268 & 0.240 & 0.28 & 0.20 & 0.93 \\
\hline 6R-CC, $15-16$ & $\mathrm{Crl}$ & 134.05 & 23 & & & 0.709141 & 0.000020 & -0.522 & 0.282 & 0.63 & 0.22 & 1.44 \\
\hline 7R-1, 14-16 & $\mathrm{Crl}$ & 140.64 & 0 & & & 0.709125 & 0.000018 & -0.747 & 0.254 & 1.04 & 0.68 & 1.53 \\
\hline $8 \mathrm{R}-\mathrm{CC}, 4-6$ & $\mathrm{Crl}$ & 150.14 & 4 & & & 0.709160 & 0.000011 & -0.254 & 0.155 & 0.28 & 0.20 & 0.91 \\
\hline 11R-CC, 2-4 & $\mathrm{Crl}$ & 169.42 & 9 & & & 0.709137 & 0.000013 & -0.578 & 0.183 & 0.63 & 0.22 & 1.44 \\
\hline $13 \mathrm{R}-\mathrm{CC}, 2-4$ & $\mathrm{Crl}$ & 188.82 & 4 & & & 0.709122 & 0.000015 & -0.790 & 0.212 & 1.04 & 0.69 & 1.54 \\
\hline $15 \mathrm{R}-\mathrm{CC}, 2-5$ & $\mathrm{Bv}$ & 208.22 & & & & 0.709134 & 0.000014 & -0.620 & 0.197 & 0.58 & 0.21 & 1.46 \\
\hline $18 \mathrm{R}-2,44-46$ & $\mathrm{Crl}$ & 238.89 & 0 & & & 0.709168 & 0.000010 & -0.141 & 0.141 & 0.27 & 0.18 & 0.37 \\
\hline $19 \mathrm{R}-\mathrm{CC}, 3-5$ & Mtx & 246.43 & 16 & & & 0.709150 & 0.000011 & -0.395 & 0.155 & 0.49 & 0.06 & 1.09 \\
\hline $21 \mathrm{R}-\mathrm{CC}, 2-3$ & $\mathrm{Crl}$ & 265.52 & 5 & & & 0.709135 & 0.000020 & -0.606 & 0.282 & 0.63 & 0.21 & 1.45 \\
\hline 24R-CC, 5-6 & $\mathrm{Crl}$ & 294.45 & 2 & & & 0.709107 & 0.000016 & -1.001 & 0.226 & 1.19 & 0.90 & 1.76 \\
\hline $25 \mathrm{R}-\mathrm{CC}, 12-14$ & $\mathrm{Crl}$ & 304.22 & 0 & & & 0.709127 & 0.000015 & -0.719 & 0.212 & 1.04 & 0.68 & 1.53 \\
\hline 27R-CC, 12-14 & $\mathrm{Crl}$ & 323.52 & 0 & & & 0.709115 & 0.000014 & -0.888 & 0.197 & 1.22 & 1.00 & 1.48 \\
\hline $30 \mathrm{R}-\mathrm{CC}, 5-7$ & $\mathrm{Crl}$ & 352.35 & 100 & & & 0.709095 & 0.000017 & -1.170 & 0.240 & 1.42 & 1.13 & 2.04 \\
\hline $32 \mathrm{R}-\mathrm{CC}, 3-5$ & Mtx & 371.63 & 100 & 1,988 & 349 & 0.709102 & 0.000009 & -1.072 & 0.127 & 1.15 & 0.79 & 1.77 \\
\hline $33 \mathrm{R}-\mathrm{CC}, 4-6$ & Mtx & 381.34 & 100 & 1,752 & 1,159 & 0.709091 & 0.000014 & -1.227 & 0.197 & 1.58 & 1.36 & 2.12 \\
\hline $34 \mathrm{R}-\mathrm{CC}, 11-13$ & Mtx & 391.11 & 100 & 1,820 & 491 & 0.709086 & 0.000014 & -1.297 & 0.197 & 1.66 & 1.41 & 2.35 \\
\hline $36 \mathrm{R}-\mathrm{CC}, 1-4$ & Mtx & 410.31 & 100 & 1,954 & 264 & 0.708839 & 0.000017 & -4.780 & 0.240 & 10.68 & 9.88 & 12.50 \\
\hline $38 \mathrm{R}-\mathrm{CC}, 7-9$ & Mtx & 429.67 & 100 & 1,779 & 207 & 0.708657 & 0.000016 & -7.347 & 0.226 & 17.29 & 17.06 & 17.63 \\
\hline 39R-CC, 6-8 & Mtx & 439.36 & 100 & 1,820 & 207 & 0.708675 & 0.000015 & -7.093 & 0.212 & 17.08 & 16.81 & 17.58 \\
\hline 40R-CC, $16-18$ & Mtx & 449.06 & 100 & 1,840 & 235 & 0.708611 & 0.000013 & -7.995 & 0.183 & 18.30 & 17.73 & 18.40 \\
\hline 41R-CC, $1-4$ & Mtx & 58.61 & 75 & 2,028 & 178 & 0.708647 & 0.000015 & -7.488 & 0.212 & 17.30 & 17.02 & 17.68 \\
\hline 47R-CC, $12-14$ & Mtx & 515.82 & 100 & 1,914 & 178 & 0.708482 & 0.000010 & -9.814 & 0.141 & 20.67 & 20.22 & 20.84 \\
\hline $48 \mathrm{R}-1,39-42$ & Mtx & 525.79 & 100 & 1,934 & 207 & 0.708515 & 0.000010 & -9.349 & 0.141 & 19.09 & 18.74 & 19.53 \\
\hline $48 \mathrm{R}-1,71-73$ & Mtx & 526.11 & 100 & 1,920 & 207 & 0.708512 & 0.000022 & -9.391 & 0.310 & 19.10 & 18.69 & 20.78 \\
\hline 49R-CC, $2-5$ & Mtx & 534.62 & 100 & 1,893 & 207 & 0.708386 & 0.000013 & -11.168 & 0.183 & 21.19 & 20.97 & 21.71 \\
\hline 55R-CC, $1-4$ & Mtx & 592.61 & 100 & 1,920 & 349 & 0.708493 & 0.000011 & -9.659 & 0.155 & 20.20 & 19.54 & 20.83 \\
\hline 57R-CC, $11-15$ & $M t x$ & 612.11 & 100 & 1,887 & 264 & 0.708234 & 0.000009 & -13.311 & 0.127 & 24.15 & 24.09 & 24.30 \\
\hline $59 \mathrm{R}-\mathrm{CC}, 1-4$ & Mtx & 631.31 & 100 & 1,873 & 200 & 0.708233 & 0.000015 & -13.325 & 0.212 & 24.16 & 24.10 & 24.29 \\
\hline $63 R-1,33-36$ & Mtx & 669.53 & 100 & 1,840 & 34 & 0.708241 & 0.000 & -13.212 & 0.197 & 24.17 & 24.03 & 24.24 \\
\hline $64 \mathrm{R}-1,33-35$ & Mtx & 678.83 & 100 & 1,8 & 15 & 0.707 & 0.000 & -16.625 & 0.282 & 30.28 & 29.34 & 31.35 \\
\hline $64 \mathrm{R}-1,45-47$ & $M t x$ & 678 & 100 & 1,8 & 16 & 0.707 & & 50 & 0.197 & 33.35 & 32.36 & 34.62 \\
\hline $64 \mathrm{R}-1,58-60$ & Mtx & 679 & 100 & 1,853 & 12 & 0.70 & & & 1 & 36.4 & 36 & 36.68 \\
\hline $64 \mathrm{R}-2,77-81$ & Mtx & 680 & 100 & 1,853 & 12 & & & & & & 34 & 34. \\
\hline $65 \mathrm{R}-\mathrm{CC}, 18-21$ & Mtx & 688.2 & 100 & 1,853 & 17 & 0.707865 & & -18.5 & 0.127 & 35.06 & 34.33 & 35.83 \\
\hline $66 \mathrm{R}-1,47-51$ & Mtx & 698.27 & 100 & 1,860 & 17 & 0.707864 & 0.000 & -18.528 & 0.240 & 35.07 & 34.02 & 36.31 \\
\hline $67 R-1,6-9$ & Mtx & 707.56 & 100 & 2,126 & 12 & 0.707807 & 0.000 & -19.332 & 0.240 & 36.47 & 36.20 & 36.57 \\
\hline $68 \mathrm{R}-1,1-3$ & Mtx & 717.11 & 100 & 2,098 & 107 & 0.707862 & 0.000017 & -18.557 & 0.240 & 35.09 & 34.38 & 36.07 \\
\hline $68 \mathrm{R}-1,44-46$ & Mtx & 717.54 & 100 & 2,098 & 136 & 0.707900 & 0.000011 & -18.021 & 0.1 & 33.34 & 32.67 & 34.52 \\
\hline $69 \mathrm{R}-1,18-23$ & Mtx & 726.98 & 100 & 2,099 & 169 & 0.707938 & 0.000013 & -17.485 & & 32.00 & 31.68 & 32.92 \\
\hline $69 \mathrm{R}-1,58-60$ & Mtx & 727.38 & 100 & 2,203 & 482 & 0.707928 & 0.000014 & -17.626 & 0.197 & 31.99 & 31.34 & 32.93 \\
\hline
\end{tabular}

${ }^{a} \mathrm{Crl}=$ coral, $\mathrm{Mtx}=$ matrix, $\mathrm{Bv}=$ bivalve.

${ }^{b} \delta^{87} \mathrm{Sr}=\left(\left(^{87} \mathrm{Sr}^{86} \mathrm{Sr}_{\text {sample }}{ }^{87} \mathrm{Sr} /^{86} \mathrm{Sr}_{\text {modem seawater }}\right)-1\right) \times 10^{5}$.

'Uncertainties refer to the least significant digits.

${ }^{\mathrm{d}}$ App. $=$ apparent age. Min. $=$ minimum age, Max. = maximum age.

$-0.516 \pm 0.231$. Seven samples, recovered from between 294.4 and 391.1 mbsf (Cores $24 \mathrm{R}$ to $34 \mathrm{R}$ ), show a trend of steadily decreasing $\delta^{87} \mathrm{Sr}$ values with increasing depth. The minimum $\delta^{87} \mathrm{Sr}$ value at the base of this interval (Core 34R) is $-1.297 \pm 0.197$. There was no recovery in Core $35 R$. The next stratigraphically-lower sample recovered was from Core $36 \mathrm{R}$, and it has a $\delta^{87} \mathrm{Sr}$ value of $-4.780 \pm 0.240$. This low value corresponds to a decrease of nearly $3.5 \delta$ units, a decrease that occurs over only $\sim 20 \mathrm{~m}$. Core $37 \mathrm{R}$ recovered no sediment, and a sample from Core $38 \mathrm{R}$ has a $\delta^{87} \mathrm{Sr}$ value of $-7.347 \pm$ 0.226 . Here again there is an abrupt decrease in $\delta$ units, this time roughly $2.5 \delta$ units, over only $\sim 20 \mathrm{~m}$. Four samples analyzed between 439.3 and 468.3 mbsf (Cores $38 \mathrm{R}$ to $41 \mathrm{R}$ ) show no discernible trend with depth, and average $-7.481 \pm 0.380$. Five samples, recovered between 515.8 and $592.6 \mathrm{mbsf}$ (Cores $47 \mathrm{R}$ to $55 \mathrm{R}$ ), have $\delta^{87} \mathrm{Sr}$ values that average $-9.876 \pm 0.747$. Three samples, recovered between 612.1 and $669.5 \mathrm{mbsf}$ (Cores 57R to 63R), have virtually identical $\delta^{87} \mathrm{Sr}$
Table 2. Stable isotopic values for selected samples at Bougainville Guyot.

\begin{tabular}{|c|c|c|c|c|}
\hline $\begin{array}{l}\text { Core, section, } \\
\text { interval }(\mathrm{cm})\end{array}$ & $\begin{array}{l}\text { Sample } \\
\text { type }\end{array}$ & $\begin{array}{l}\text { Depth } \\
\text { (mbsf) }\end{array}$ & $\begin{array}{c}\delta^{18} \mathrm{O} \\
(\% \circ \text { PDB })\end{array}$ & $\begin{array}{c}\delta^{13} \mathrm{C} \\
(\% o \text { PDB })\end{array}$ \\
\hline \multicolumn{5}{|l|}{$134-831-$} \\
\hline $48-1,1-3$ & Spar & 525.38 & 2.52 & -0.95 \\
\hline $48-1,1-3$ & Spar & 525.38 & 1.91 & -1.17 \\
\hline $48-1,39-42$ & Spar & 525.79 & 2.48 & -1.31 \\
\hline $48-1,71-73$ & Spar & 526.11 & 2.48 & -0.93 \\
\hline $48-1,71-73$ & Spar & 526.11 & 2.49 & -1.19 \\
\hline $49-\mathrm{CC}, 2-5$ & Spar & 534.62 & 2.63 & -1.57 \\
\hline $57-\mathrm{CC}, 11-15$ & Spar & 612.11 & -2.57 & -5.48 \\
\hline $63-1,33-36$ & Spar & 669.53 & 1.28 & -2.00 \\
\hline $65-\mathrm{CC}, 18-21$ & Spar & 688.28 & -2.80 & -5.53 \\
\hline $65-\mathrm{CC}, 18-21$ & Spar & 688.28 & -3.69 & -5.44 \\
\hline $67-1,6-9$ & Spar & 707.56 & 2.02 & -2.34 \\
\hline
\end{tabular}

Note: Spar $=$ sparry calcite cement. 


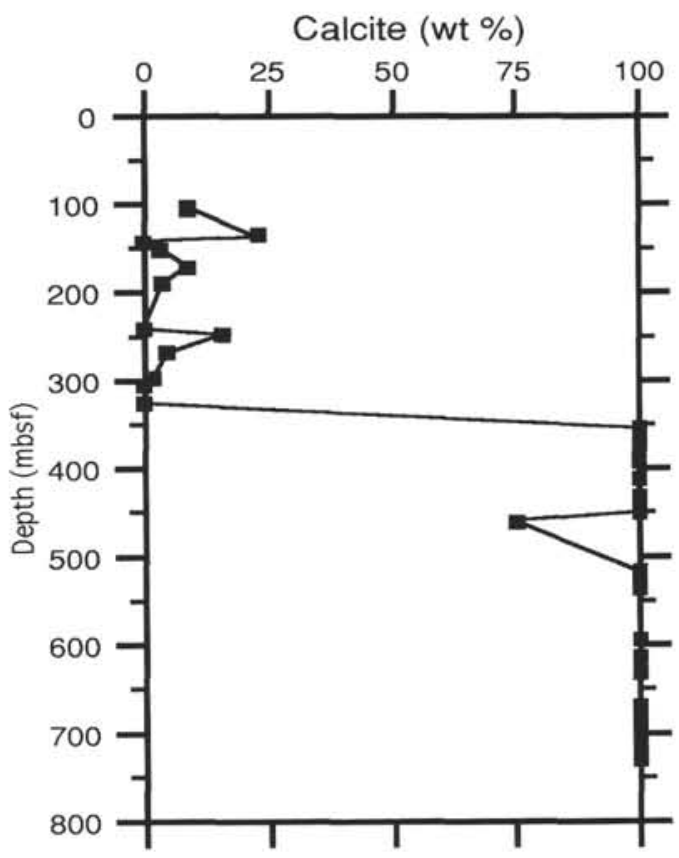

Figure 3. Mineralogic changes with depth in Hole $831 \mathrm{~B}$. The upper $-320 \mathrm{~m}$ of Bougainville Guyot remains largely aragonitic, in contrast to the lower -400 $\mathrm{m}$, which is pervasively calcitized. Sample at $458.61 \mathrm{mbsf}$ contains $\sim 25 \%$ dolomite by weight.

values (average is $-13.283 \pm 0.062$ ). Samples recovered from 678.8 to $707.5 \mathrm{mbsf}$ (Cores $64 \mathrm{R}$ to $67 \mathrm{R}$ ) have a general trend of decreasing $\delta^{87} \mathrm{Sr}$ values with increasing depth. The lowest $\delta^{87} \mathrm{Sr}$ value, -19.332 \pm 0.240 , occurs at the base of this interval. Four samples from the remaining $\sim 10 \mathrm{~m}$ of the carbonate cap in Hole $831 \mathrm{~B}$ show a reversed trend: increasing $\delta^{87} \mathrm{Sr}$ values with increasing depth (Fig. 6A). Such a reversal in the expected trend is most likely the result of post-depositional rock-water interaction.

\section{Chronostratigraphy}

The chronostratigraphy of Bougainville Guyot can be subdivided into three intervals: (1) a Pleistocene interval (102.4 to $391.11 \mathrm{mbsf}$ ); (2) a Miocene interval (410.31 to $669.53 \mathrm{mbsf}$ ); and (3) an Oligocene interval (678.83 to $727.50 \mathrm{mbsf}$ ) (Fig. 6B).

The Pleistocene sequence is defined by data from 18 samples recovered between 102.40 and $391.11 \mathrm{mbsf}$, which yield ages between 0.28 to $1.66 \mathrm{Ma}$ (Fig. 6B). Two chronologic intervals can be distinguished within the Pleistocene portion of the carbonate cap: an upper interval where sample age is relatively invariant, and a lower interval where sample age tends to increase with increasing depth. Sample age from the upper interval, from 102.40 to 265.62 mbsf, averages $0.59 \pm$ $0.27 \mathrm{Ma}$. A sample from the base of the lower interval is dated at 1.66 $\mathrm{Ma}$ (minimum age of $1.41 \mathrm{Ma}$ and a maximum age of $2.35 \mathrm{Ma}$ ).

The Miocene sequence is defined by 13 samples, recovered between 410.31 and 669.53 mbsf, which yield ages ranging from 10.68 $\mathrm{Ma}$ (minimum age of $9.88 \mathrm{Ma}$ and a maximum age of $12.50 \mathrm{Ma}$ ) to $24.17 \mathrm{Ma}$ (minimum age of $24.03 \mathrm{Ma}$ and a maximum age of 24.24 Ma). Within the Miocene sequence, there are several significant "age jumps" (i.e., abrupt increases in age) with increasing depth. For example, a sample from $410.31 \mathrm{mbsf}$ (Core 36R) has a latest middle Miocene age $(10.68 \mathrm{Ma})$, whereas the next stratigraphically lower sample, from $429.67 \mathrm{mbsf}$ (Core 38R), has a latest lower Miocene age (17.29 Ma; minimum age of $17.06 \mathrm{Ma}$ and a maximum age of 17.63 Ma). In fact, this latest lower Miocene sample is only one of four samples that consistently yield such an age estimate (mean = 17.49 $\mathrm{Ma} \pm 0.55$ ). This latest lower Miocene interval spans a depth range of $429.67 \mathrm{mbsf}$ (Core 38R) to $458.61 \mathrm{mbsf}$ (Core 4IR). Five samples from 515.82 to $592.61 \mathrm{mbsf}$ (Cores $47 \mathrm{R}$ to $55 \mathrm{R}$ ) have an average apparent age of $20.1 \pm 0.94 \mathrm{Ma}$. The three stratigraphically lower samples, from 612.11 to $669.53 \mathrm{mbsf}$ (Cores 57 to 63R), have virtually identical apparent ages (average is $24.2 \pm 0.01 \mathrm{Ma}$ ).
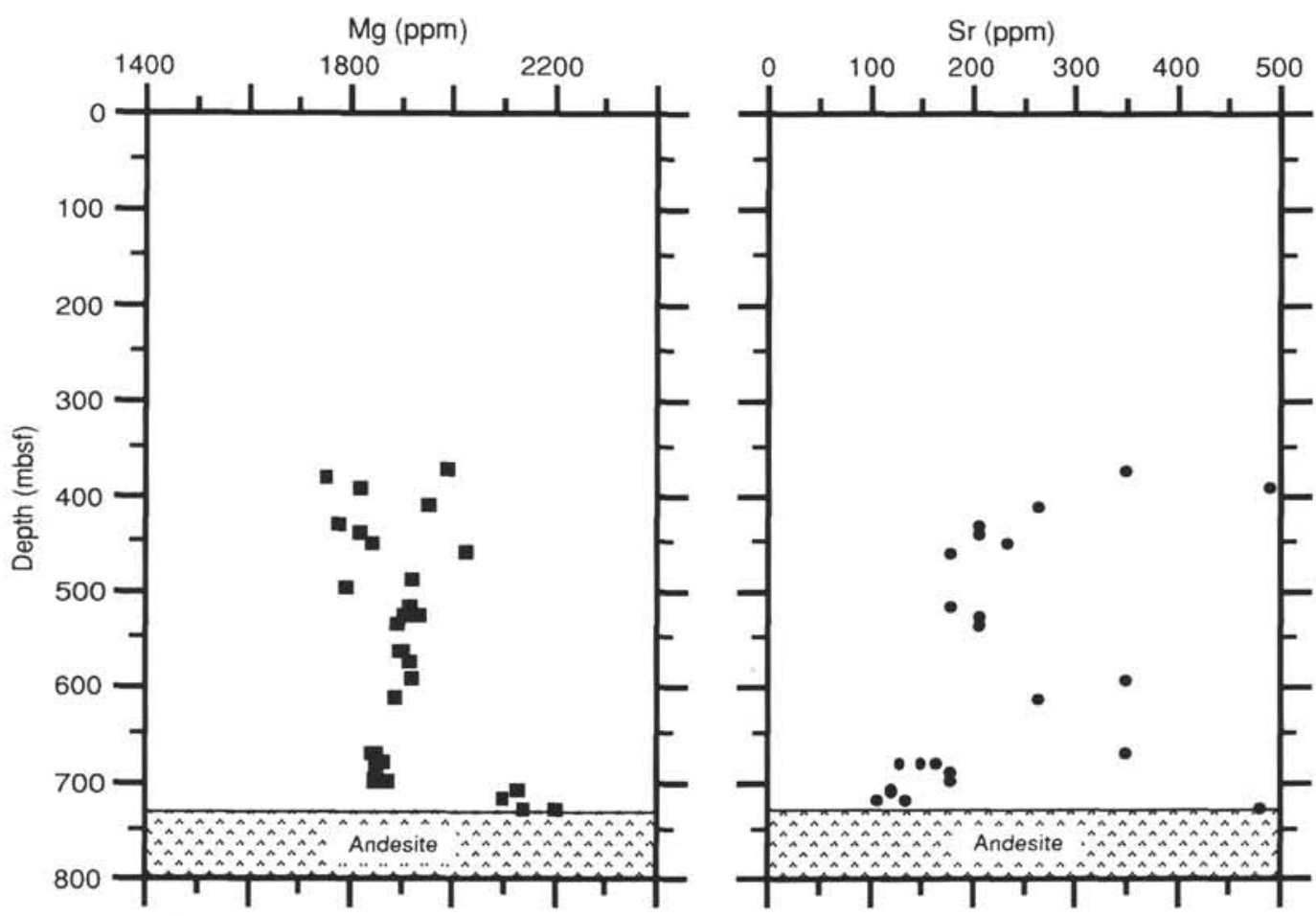

Figure 4. $\mathrm{Mg}$ and $\mathrm{Sr}$ content variation with depth in Hole 83IB. Samples analyzed for $\mathrm{Mg}$ and $\mathrm{Sr}$ content were $100 \%$ calcite Samples near the base of the carbonate cap show a trend of higher Mg contents and lower Sr contents relative to overlying samples. 


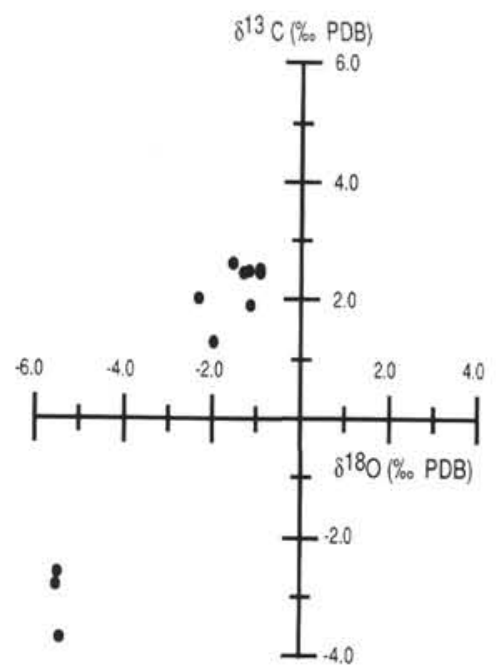

Figure $5 . \delta^{18} \mathrm{O}$ vs. $\delta^{13} \mathrm{C}$ for selected sparry calcite cement samples (Table 2). Data tend to cluster into two groups. The first group has average $\delta^{18} \mathrm{O}$ (\% PDB) and $\delta^{13} \mathrm{C}(\% \mathrm{PDB})$ values of $-1.43 \pm 0.51(2 \sigma)$ and $2.23 \pm 0.46(2 \sigma)$, respectively. The second group has average $\delta^{18} \mathrm{O}\left(\%\right.$ PDB) and $\delta^{13} \mathrm{C}(\% \mathrm{PDB})$ values of $-5.48 \pm 0.04(2 \sigma)$ and $-3.02 \pm 0.59(2 \sigma)$, respectively. The latter cement samples are interpreted to have been precipitated in the meteoric environment, whereas the former cement samples were most likely precipitated in the marine environment.

The apparent age of the Oligocene sequence ranges from slightly greater than $25 \mathrm{Ma}$ to roughly $36.5 \mathrm{Ma}$. However, four samples from the lowermost $10 \mathrm{~m}$ of the carbonate cap at Bougainville Guyot show a decrease in age with increasing depth (Fig. 6B). We attribute this age reversal to be the product of post-depositional rock-water interaction.

\section{DISCUSSION}

The carbonate cap at Bougainville Guyot is readily divisible into two primary chronostratigraphic sequences: (1) a shallow $(<400$ mbsf), mostly aragonitic, Quaternary sequence, and (2) a deep ( $>400$ mbsf to $<728 \mathrm{mbsf}$ ), mostly calcitic, Oligocene to Miocene sequence. These two sequences will be discussed separately in the subsequent discussion.

\section{Quaternary Carbonates}

The Quaternary sequence at Bougainville Guyot is approximately $400 \mathrm{~m}$ thick and is composed of coral-mollusk floatstone. Quaternary carbonates remain largely unaltered (i.e., aragonitic), except for the interval from 352.35 to 391.11 mbsf, which is pervasively calcitized. The transition in mineralogy from aragonitic sediment to calcitized limestone occurs somewhere between 323.52 (Core 27R) and 352.35 mbsf (Core $30 \mathrm{R}$ ). Interestingly, Sr-isotope ages are not discernibly different across this mineralogical boundary. This abrupt change in mineralogy is most likely a diagenetic boundary resulting from subaerial exposure attendant with a relative sea-level fall shortly after sediment deposition in the early Pleistocene. The lack of change in the $\mathrm{Sr}$-isotope age across this mineralogical transition suggests that hiatus duration must be less than the roughly $0.3-\mathrm{m}$.y. temporal resolution of $\mathrm{Sr}$-isotope chronostratigraphy during this time interval.

Two possible subunits occur within the Quaternary sequence. The first subunit occurs from 102.40 to 265.62 mbsf and 11 samples from this interval have an average apparent age of $0.59 \pm 0.27 \mathrm{Ma}$. The second subunit occurs from $>265.52$ to 391.11 mbsf and, perhaps, to a depth of $<410.31$ mbsf. Seven samples from this second subunit have an average apparent age of $1.32 \pm 0.23 \mathrm{Ma}$. In addition, evidence of carbonate dissolution (i.e., moldic and vuggy porosity) is first recognized in the second subunit of the Quaternary sequence.
One remaining problem exists with our estimates of apparent age for the Quaternary sequence. Uranium-thorium mass spectrometric analyses of several samples from $<400$ mbsf at Bougainville Guyot yield consistently younger ages than our $\mathrm{Sr}$-isotope ages (Edwards et al., 1991). For example, a coral sample from Core 27R (134-831B$27 R-C C, 12-14 \mathrm{~cm}$ ) yields a ${ }^{230} \mathrm{Th}$ age of $0.393 \mathrm{Ma}$ and a ${ }^{234} \mathrm{U} /{ }^{238} \mathrm{U}$ age of $0.371 \mathrm{Ma}$ (Edwards et al., 1991), whereas the same sample yields a Sr-isotope age of $1.22 \mathrm{Ma}$ (minimum age of $1.00 \mathrm{Ma}$ and a maximum age of 1.48). Additional work is required to determine the cause of this age discrepancy.

\section{Oligocene to Miocene Carbonates}

The pervasively calcitized interval occurs from 410.31 to 727.50 mbsf and can be subdivided into a Miocene interval (410.31 to 669.53 mbsf) and an Oligocene interval (678.83 to $727.50 \mathrm{mbsf}$ ). Specifically, four abrupt transitions of increasing age with increasing depth occur in the Miocene interval. These four subunits within the Miocene document periods of sediment accumulation at $\sim 10.68 \mathrm{Ma}(\mathrm{N}=1)$, $17.49 \mathrm{Ma} \pm 0.55(\mathrm{~N}=4), 20.1 \pm 0.94 \mathrm{Ma}(\mathrm{N}=5)$, and $24.2 \pm 0.01 \mathrm{Ma}$ $(\mathrm{N}=3)$. Two periods of sediment accumulation occur in the Oligocene sequence: one at $30.28 \mathrm{Ma}(\mathrm{N}=1)$ and a second from $33.35 \mathrm{Ma}$ to $36.47 \mathrm{Ma}(\mathrm{N}=6)$. Shipboard biostratigraphic analyses (Fig. 2) identified lower Miocene ( 21.8 Ma to $23.6 \mathrm{Ma}$ ) limestones from 563.6 to $621.6 \mathrm{mbsf}$ and upper Oligocene ( $23.6 \mathrm{Ma}$ to $28.2 \mathrm{Ma}$ ) limestones from 621.6 to 727.5 mbsf. Our Sr-isotope age estimates agree well with the biostratigraphically identified early Miocene interval and is consistent with, to slightly older than, the biostratigraphically identified late Oligocene interval.

Periods of sediment accumulation in the Oligocene to Miocene sequence at Bougainville Guyot are separated by $\sim 2$ to 9 m.y. of nondeposition. Similar patterns of alternation between periods of sediment accumulation and periods of nondeposition, recognized in other carbonate sequences (e.g., Anewetak Atoll; Ludwig et al., 1988; Saller and Koepnick, 1990; Quinn et al., 1991), have been attributed to be the product of relative sea-level rise (i.e., sediment accumulation) and relative sea-level fall (i.e., subaerial exposure, nondeposition, and meteoric diagenesis). Indeed, stable isotope values of calcite cement samples from 612.11 and 688.28 mbsf (Table 2 and Fig. 5) are consistent with cement precipitation in the meteoric environment. Thus, periods of nondeposition, ranging in duration from $\sim 2$ to 9 m.y., are most likely the product of subaerial exposure in response to a relative sea-level fall.

\section{CONCLUSIONS}

Mineralogy, minor element, and strontium-isotope study of neritic carbonates recovered at Hole $831 \mathrm{~B}$ (Bougainville Guyot) lead to the following conclusions:

1. An abrupt transition from aragonite-rich sediment to completely calcitized sediment occurs within material of similar age (early Pleistocene). This abrupt change in mineralogy is a diagenetic boundary that resulted from subaerial exposure attendant with a relative sealevel fall shortly after sediment deposition in the early Pleistocene.

2. The chronostratigraphy of Bougainville Guyot can be subdivided into three intervals: (1) a Pleistocene interval (102.4 to 391.11 mbsf); (2) a Miocene interval (410.31 to $669.53 \mathrm{mbsf}$ ); and (3) an Oligocene interval (678.83 to $727.50 \mathrm{mbsf}$ ).

3. Sr-isotope data indicate that periods of sediment accumulation (relative sea-level rise) are separated by periods of nondeposition (relative sea-level fall). The latter are recognized as disconformities (i.e., stratigraphically abrupt decreases in $\delta^{87} \mathrm{Sr}$ ) in the Sr-isotope stratigraphy. $\delta^{87} \mathrm{Sr}$ disconformities are most likely the product of subaerial exposure in response to a relative sea-level fall.

4. Hiatus duration across the identified $\delta^{87} \mathrm{Sr}$ disconformities ranges from $\sim 2$ to 9 m.y. 


\section{REFERENCES}

Collot, J.-Y., Lallemand, S., Pelletier, B., Eissen, J.-P., Glaçon, G., Fisher M.A., Greene, H.G., Boulin, J., Daniel, J., and Monzier, M., 1992. Geology of the d'Entrecastaux-New Hebrides island arc collision: results from a deep-sea submersible survey. Tectonophysics, 212:213-241.

DePaolo, D.J., 1986. Detailed record of the Neogene $\mathrm{Sr}$ isotopic evolution of seawater from DSDP Site 590B. Geology: 14:103-106.

Edwards, R.L., Gallup, C.G., Taylor, F.W., Quinn, T.M., and ODP Leg 134 Scientific Party, 1991. ${ }^{230} \mathrm{Th} /{ }^{238} \mathrm{U}$ and ${ }^{2.34} \mathrm{U} /{ }^{238} \mathrm{U}$ in submarine corals: evidence for diagenetic leaching of ${ }^{234} \mathrm{U}$. Eos, 72:535.

Hess, J., Bender, M.L., and Schilling, J.G., 1986. Evolution of the ratio of strontium-87 to strontium-86 in seawater from Cretaceous to Present. Science, 231:979-984.

Hodell, D.A., Mead, G.A., and Mueller, P.A., 1990. Variation in the strontium isotopic composition of seawater ( $8 \mathrm{Ma}$ to present): implications for chemical weathering rates and dissolved fluxes to the oceans. Chem. Geol. (Isotope Geosci. Sect.), 80:291-307.

Hodell, D.A., Mueller, P.A., and Garrido, J.R., 1991. Variations in the strontium isotopic composition of seawater during the Neogene. Geology, 19:24-27.

Hodell, D.A., Mueller, P.A., McKenzie, J.A., and Mead, G.A., 1989. Strontium isotope stratigraphy and geochemistry of the late Neogene ocean. Earth Planet. Sci. Lett., 92:165-178.

Ludwig, K.R., 1990. ISOPLOT-a plotting and regression program for radiogenic-isotope data, for IBM-PC compatible computers. Open-File Rep.U.S. Geol. Surv., 88-557:44.

Ludwig, K.R., Halley, R.B., Simmons, K.R., and Peterman Z.E., 1988, Sr isotope stratigraphy of Enewetak Atoll. Geology, 16:173-177.

Montaggioni, L., Butterlin, J., Glaçon, G., Collot, J.-Y., Monzier, M., Pelletier, B., Boulin, J., Lallemand, S., Daniel, J., Faure, G., Lauriat-Rage, A.
Venec-Peyre, M.T., Blondeau, A., Lozouet, P., Vacelet, J., and Babinot, J.F., in press. Results of SUBPSO I dives: geodynamical significance of platform carbonates subducting beneath the New Hebrides island arc (South-West Pacific). C. R. Acad. Sci. Ser. 2.

Quinn, T.M., 1991. Meteoric diagenesis of post-Miocene limestones on Enewetak Atoll. J. Sediment. Petrol., 61:681-703.

Quinn, T.M., Lohmann, K.C., and Halliday, A.N., 1991. Sr isotopic variation in shallow water carbonate sequences: stratigraphic, chronostratigraphic, and eustatic implications of the record at Enewetak Atoll. Paleoceanography, 6:371-385.

Saller, A.H., and Koepnick, R.B., 1990. Eocene to early Miocene growth of Enewetak Atoll: insight from strontium isotope data. Geol. Soc. Am. Bull., $102: 381-390$

Swart, P.K., Ruiz, J., and Holmes, C.W., 1987. Use of strontium isotopes to constrain the timing and mode of dolomitization of upper Cenozoic sediments in a core from San Salvador, Bahamas. Geology, 15:262-265.

Vahrenkamp, V.C., Swart, P.K., and Ruiz, J., 1988. Constraints and interpretation of ${ }^{87} \mathrm{Sr} /{ }^{86} \mathrm{Sr}$ ratios in Cenozoic dolomites. Geophys. Res. Lett., 15:385-388.

\footnotetext{
Abbreviations for names of organizations and publications in ODP reference lists follow the style given in Chemical Abstracts Service Source Index (published by American Chemical Society).
}

Date of initial receipt: 15 April 1992

Date of acceptance: 14 June 1993

Ms 134SR-006

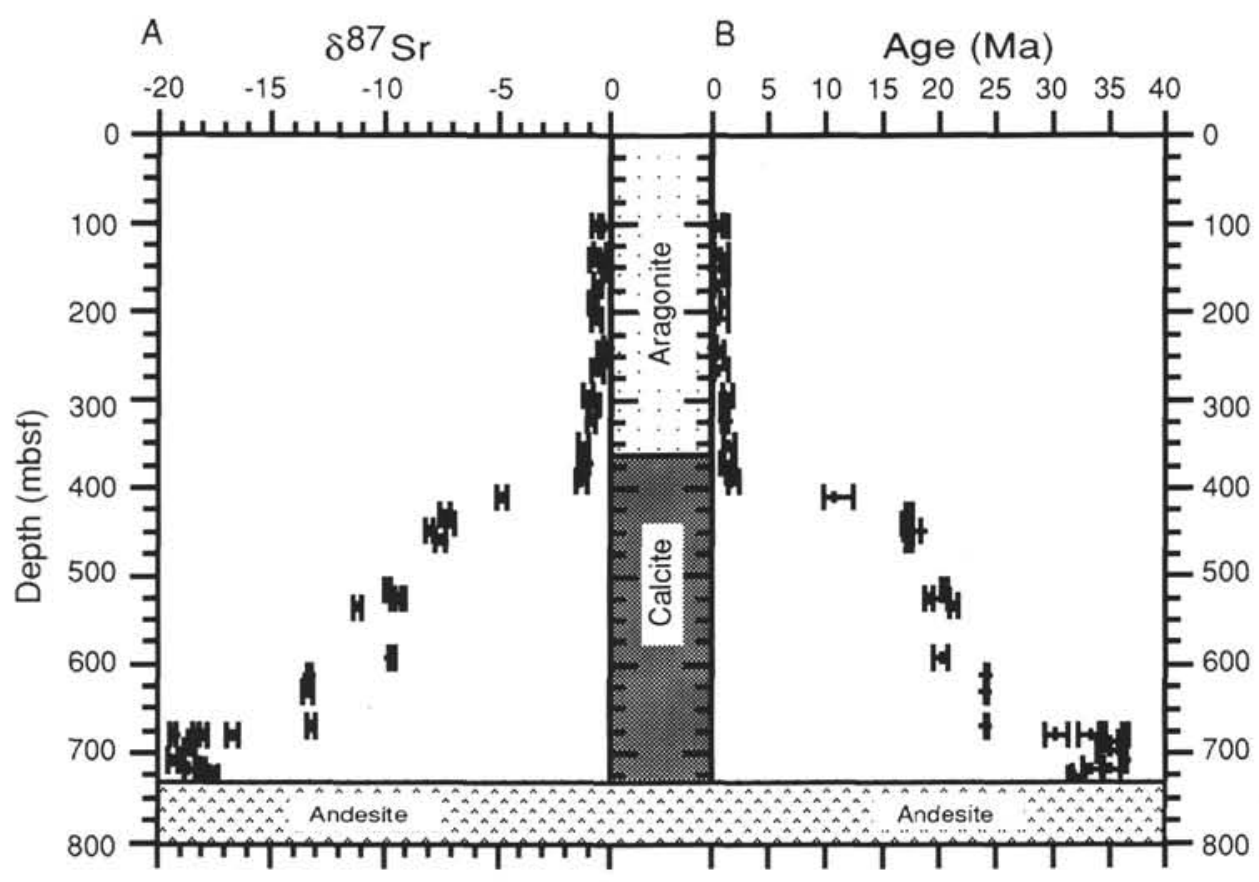

Figure 6. A. Sr-isotopic variation with depth in Hole 831B. Two trends are worthy of note. First, there is the trend of decreasing $\delta^{87} \mathrm{Sr}$ values with increasing depth except in the lowermost $20 \mathrm{~m}$ of the carbonate cap. Second, abrupt decreases in $\delta^{87} \mathrm{Sr}$ values occur over relatively small depth intervals. B. Sr-isotopic variation with time in Hole 831B. Trends similar to those noted in (A) are also present in (B). Sr-isotope data delineates three primary periods of sediment accumulation: (1) Pleistocene (102.4 to $391.11 \mathrm{mbsf}$ ); (2) Miocene ( 410.31 to $669.53 \mathrm{mbsf}$ ); and (3) Oligocene (678.83 to $727.50 \mathrm{mbsf}$ ). Several disconformities are recognized within each of these periods of sediment accumulation and document intervals of nondeposition, relative sea-level fall, subaerial exposure, and meteoric diagenesis. 